TITLE:

\title{
Ultrasonographic visualization of bleeding sites can help control postpartum hemorrhage using intrauterine balloon tamponade.
}

\section{AUTHOR(S):}

Kondoh, Eiji; Konishi, Mitsunaga; Kariya, Yoshitaka; Konishi, Ikuo

\section{CITATION:}

Kondoh, Eiji ...[et al]. Ultrasonographic visualization of bleeding sites can help control postpartum hemorrhage using intrauterine balloon tamponade.. Journal of clinical ultrasound: JCU 2014, 43(1): 23-25

\section{ISSUE DATE:}

2014-09-02

URL:

http://hdl.handle.net/2433/198651

\section{RIGHT:}

This is the peer reviewed version of the following article: Kondoh. E. Konishi, M. Kariya, Y. and Konishi, I. (2015), Ultrasonographic visualization of bleeding sites can help control postpartum hemorrhage using intrauterine balloon tamponade. J. Clin. Ultrasound, 43: 23-25, which has been published in final form at

http://dx.doi.org/10.1002/jcu.22228:; 許諾条件により本文ファイルは2015-09-02に公開:; This is not the published version. Please cite only the published version.; この論文は出版社版でありません。引用の際には出版社版をご確認じ 利用ください。 


\section{Abstract}

Identification of precise bleeding sites is generally important to control haemorrhage. Nevertheless, the optimal technique to detect the bleeding sites has not yet been fully defined for patients with life-threatening postpartum haemorrhage. We describe that ultrasonographic visualisation of bleeding sites can help control postpartum haemorrhage using intrauterine balloon tamponade.

\section{Key words}

Balloon tamponade, bleeding sites, postpartum haemorrhage, ultrasonography, uterine atony 


\section{Introduction}

Postpartum haemorrhage (PPH) is the most important cause of maternal

death worldwide ${ }^{(1)}$. PPH is largely caused by uterine atony ${ }^{(1)}$. . Clinical evaluation, usually in combination with ultrasound examination, identifies an underlying cause of $\mathrm{PPH}$, such as uterine atony, uterine inversion, or retained products of conception. Nevertheless, intractable PPH can sometimes occur with seemingly unknown causes, and the bleeding resists conventional conservative treatments. The key to management of intractable PPH is to identify the cause of bleeding and to initiate appropriate intervention immediately. We found that intrauterine balloons could be confidently placed to control PPH by visualisation of the bleeding sites using ultrasonography.

\section{Case report}

A 32-year-old nulliparous woman underwent caesarean section at 37 weeks of gestation due to severe preeclampsia and breech presentation. Two hours after surgery, a boggy uterus was observed, and approximately 650 g clots were expelled 
from the uterine cavity. The uterus became firm and well contracted following evacuation of all uterine contents. However, the bleeding (130 g/hour) persisted, and the accumulation of clots (430 g) in the uterine cavity recurred within two hours despite the administration of uterotonic drugs, including oxytocin (20 units), methylergonovine maleate $(0.2 \mathrm{mg})$, and oral misoprostol (400 $\mu \mathrm{g})$. Her blood pressure was 144/98 mmHg; pulse, 88 beats per minute. Laboratory data were as follows: haemoglobin $10.5 \mathrm{~g} / \mathrm{dl}$, haematocrit 32.0\%, and platelet count $191 \times 10^{9} / \mathrm{l}$. Type 2 uterine bleeding ${ }^{(2)}$, which seemingly presented with uterine atony, was strongly suspected from clinical manifestation. As Type 2 uterine bleeding is typified by bleeding from a disrupted artery at the upper part of the uterus ${ }^{(2)}$, trans-abdominal Colour Doppler ultrasound examination (Voluson S8, convex transducer [2-5 MHz[; GE Healthcare, Milwaukee, WI) was conducted to explore bleeding sites. Active arterial bleeding was readily visualised from the posterior part of the upper uterine cavity (Figure 1). A Bakri balloon was then placed in the upper part of the uterus and was inflated with $350 \mathrm{~mL}$ of normal saline. An ultrasound confirmed that the surface of the balloon tightly compressed the bleeding vessel (Figure 2). Despite temporary control of bleeding (less than 30 minutes), recurrent uterine bleeding occurred due to 
displacement of the intrauterine balloon towards the vagina. Consistently, active arterial bleeding was seen again using ultrasonography. Therefore, the Bakri balloon was reinserted into the uterine cavity, and each side of the uterine cervix was clamped with forceps, as previously reported ${ }^{(3)}$. The balloon remained properly positioned within the uterine cavity, and the bleeding stopped. The amount of post-operative blood loss was $1300 \mathrm{~g}$, and a blood transfusion was not needed.

\section{Discussion}

$\mathrm{PPH}$ is the leading cause of maternal mortality ${ }^{(1)}$. Persistent uterine bleeding with seemingly unknown causes can be classified into three types: Type 1 , bleeding from a disrupted artery at the lower part of the uterus; Type 2, bleeding from a disrupted artery at the upper part of the uterus; and Type 3, bleeding due to uterine atony ${ }^{(2)}$. Uterine bleeding of Type 1 and Type 2 is not stopped by uterotonics alone, while Type 3 is successfully controlled with uterotonic agents. Although both Types 2 and 3 have long been categorised as "uterine atony”, Type 2 bleeding, a subtype of conventional "uterine atony" in intractable $\mathrm{PPH}$, cannot be resolved by the enhancement of uterine contractions alone. According most common protocols, 
after use of uterotonic drugs, placement of a Bakri balloon is indicated. However, the

Bakri balloon fails to control bleeding in $12.5 \%$ of $\mathrm{PPH}{ }^{(4)}$, probably partially due to failure of direct compression of the bleeding site by balloon tamponade. Identification of the precise bleeding site is therefore important to manage intractable PPH. Although the sites of active bleeding can be detected on gray scale and color Doppler imaging ${ }^{(5,6)}$, the usefulness of ultrasound assessment of uterine bleeding sites has not been reported in the context of management of intractable $\mathrm{PPH}$ due to uterine atomy. The present case shows that prompt conservative intervention using a Bakri balloon in combination with ultrasonographic visualisation of bleeding sites can prevent serious $\mathrm{PPH}$.

\section{References}

(1) ACOG Practice Bulletin: Clinical Management Guidelines for Obstetrician-Gynecologists Number 76, October 2006: postpartum hemorrhage. Obstet Gynecol 2006;108:1039.

(2) Kawamura Y, Kondoh E, Hamanishi J, et al. Treatment decision-making for post-partum haemorrhage using dynamic contrast-enhanced computed tomography. J 
Obstet Gynaecol Res. 2014;40:67.

(3) Kawamura A, Kondoh E, Hamanishi J, et al. Cervical clamp with ring forceps to prevent prolapse of an intrauterine balloon in the management of postpartum haemorrhage. J Obstet Gynaecol Res. 2013; 39: 733.

(4) Condous GS, Arulkumaran S, Symonds I, et al. The "tamponade test" in the management of massive postpartum hemorrhage. Obstet Gynecol. 2003;101:767.

(5) Bisset RA1, Khan AN. Detection of active bleeding from a transitional cell carcinoma of the bladder by ultrasonography. J Clin Ultrasound. 1987;15:269.

(6) Seidler M1, Sayegh K, Roy A, et al. A fatal complication of ultrasound-guided abdominal paracentesis. J Clin Ultrasound. 2013;41:457.

\section{Figure Legends}

Figure 1. Ultrasonographic visualisation of uterine bleeding site.

Trans-abdominal Colour Doppler ultrasound image shows a jet (arrow) of blood flow (upper panel), and duplex Doppler ultrasound image demonstrates low-resistance type of arterial blood flow (arrowhead) towards the cavity from the posterior part of the uterus (lower panel). 
Figure 2. Ultrasonographic confirmation of Bakri balloon placement into the upper part of the uterine cavity (solid lines are added to show the outline of the uterus), where the bleeding vessel (arrow) was tightly opposed by the surface of the balloon (dashed line). 

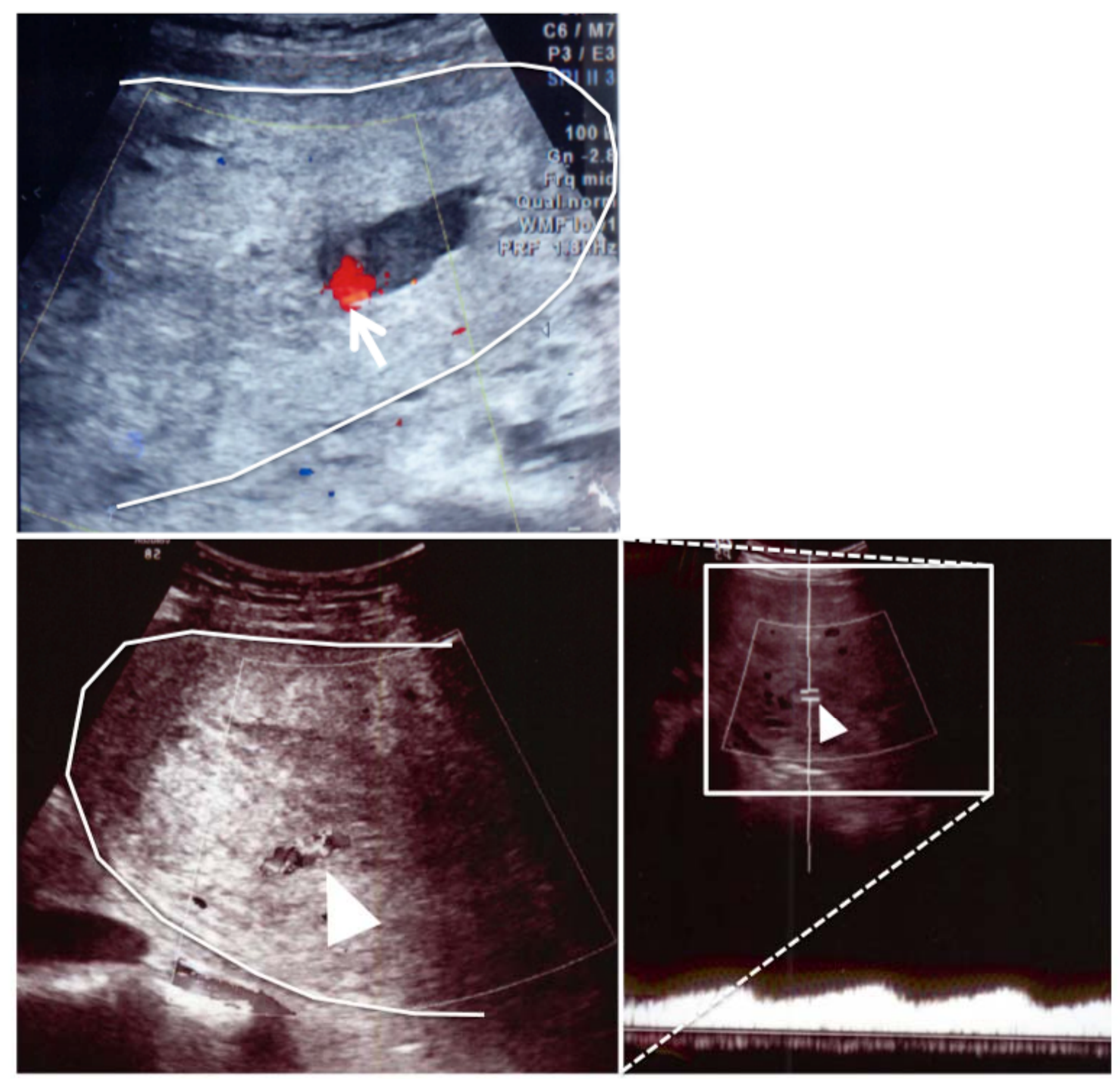

Figure 1 


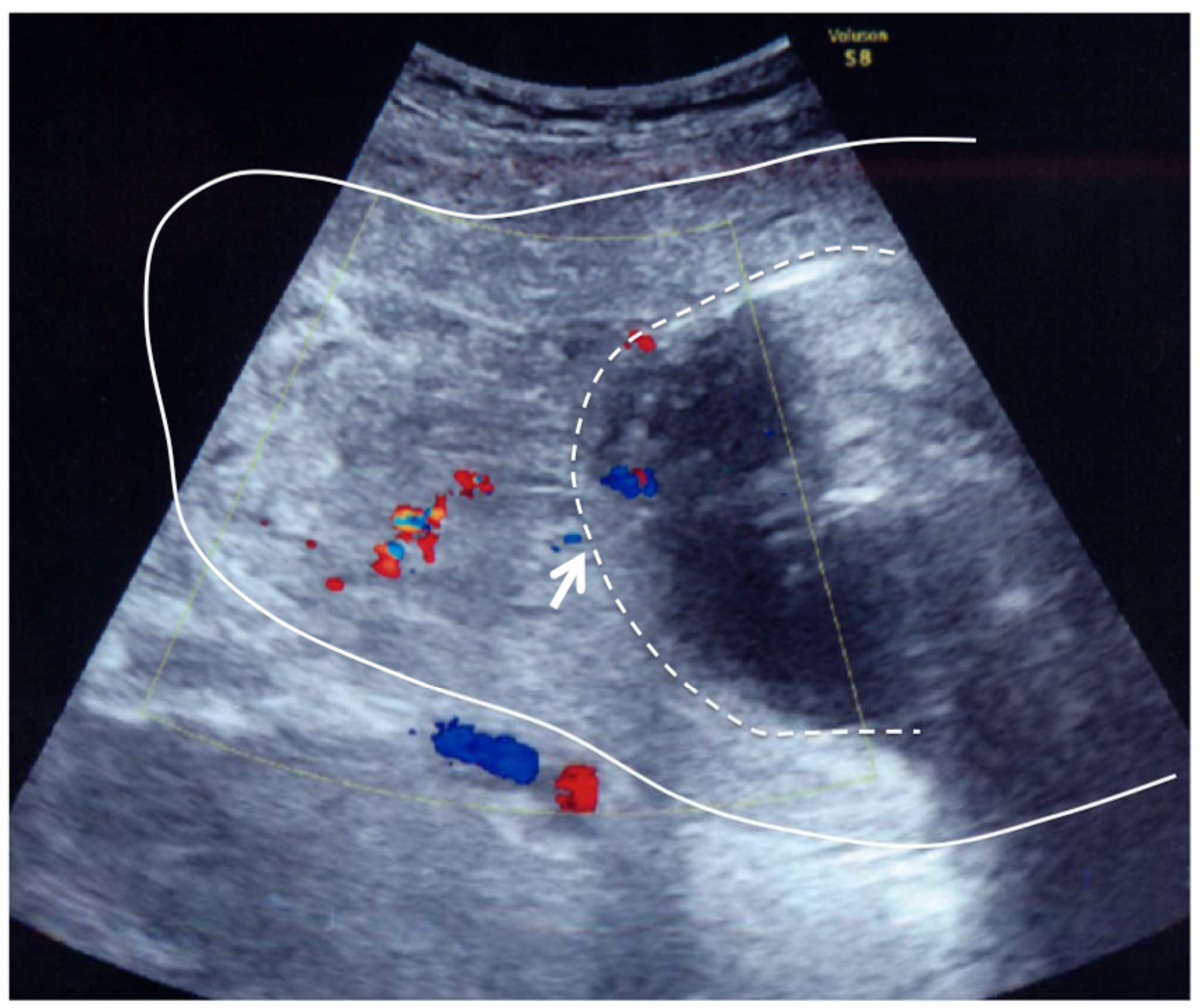

Figure 2 